\title{
Research on Narrative Time in Natsume Soseki's The Gate -- From the Perspective of Social Ethics
}

\author{
Jiao $\mathrm{Li}^{1, \mathrm{a}}$ \\ ${ }^{1}$ Japanese Department, School of Foreign Languages, Suzhou University of Science and \\ Technology, Suzhou, Jiangsu Province, China \\ alikyo@foxmail.com
}

Keywords: Narrative Time; Natsume Soseki; Social Ethics.

\begin{abstract}
Narrative time now plays an increasingly important role in literary criticism. As one of the masters of modern Japanese literature, Natsume Soseki broke the traditional linear narrative mode, and used nonlinear narrative time, durations combined fast and slow speeds, frequencies alternated with simple and repeated paces, and paid attention to psychology time in his novel The Gate. This kind of narrative time mode can vividly reflect characters' mental states, and deepen the themes of literary works. It inspires readers to think and choose, and has profound guiding significance for social ethics.
\end{abstract}

\section{Natsume Soseki and His Novel The Gate}

Natsume Soseki (1867-1916) was one of the most outstanding writers in the history of modern Japanese literature. He was also an excellent author with speculative philosophy thinking and artistic expressive force in the history of world literature. Though he has been departed for one hundred years, Soseki still enjoys admiration and high reputation from Japanese citizens. Natsume Soseki wrote two books on literary theory, fifteen novels, large quantity of essays, poems, haikus and other literary works in just twelve years. These works show readers his rich spiritual world and outstanding artistic talent, and set up a monument in literature history.

The Gate was written in 1910. It was the third in a trilogy of novels begun by Sanshiro and And Then. The book was first serialized in Asahi Shinbun, or Morning Sun Newspaper in Japan. It can be regarded as the ending of the trilogy of love tragedy, and the beginning of Natsume Soseki's later works. In the novel, the hero Sosuke fell in love and married with Oyone, the fiancee of his friend Yasui. They were detested by the whole society, and chose to live in a house without sunshine. They tasted the sweet of love and bitter of guilty, and were trapped in a dilemma which they cannot extricate themselves. The society could not accept their sincere love. The book describes a tragedy of human nature, and reflects the torturing spiritual world of intellectuals. They pursue personal happiness, but they cannot get rid of the shackles of moral ethics. The Gate is one of the representative works of Natsume Soseki's anti-naturalism. The author combined the writing techniques of Realism and Romanticism, and created a sentimental world.

\section{Narratology and Narrative Time}

Narratology is a new literary criticism theory which originated in 1960s. Narratology systematically analyzed narrative processes, narrative relations and narrative mechanisms in literary works. In 1960s, it developed rapidly and widely. After two decades, Narratology was introduced to China. Narratology focuses on the study of narrative mechanism in literary works, including time, person, operation rules, structures and expression ways. It is a kind of text centered formalism. Narratology helps us to find out the basic writing principles and norms, as well as the intrinsic links between various narrative phenomena. Thus, is has academic values and contributes to literary criticism [1].

Narrative time is one of the important issues in Narratology. The concept of narrative time is put forward to study the relationship between narrative text and the story. In fact, there are two time lines 
in each text. One is the discourse time, the other is the story time. The famous French structuralism scholar, Tzvetan Todorov pointed out, "Story time refers to the actual duration of events in the story. It is the sequence of events and the length of time that passes in the story. Discourse-time, on the other hand, covers the length of time that is taken up by the telling (or reading) of the story and the sequence of events as they are presented in discourse." [2] The "story time" is not continuous. In real life, time cannot be changed by any external force. But authors can change the story time to achieve their own creation purposes. It can be extended or shortened, suspended or stopped. [3] So in Narratology, the study of narrative time should include both "discourse time" and "story time".

In addition, narrative time also refers to "real time" and "novel time", the "description time" and "described time". It is worth noting that, the real time is different from novel time. At the same time, the novel time not only refers to described time, it also includes the description time. In this way, storytelling is not one-way or one-dimensional. The author can cut the story, and link them again by using sequential narration, inverted sequence, flashback and narration interposed. By rearranging these "tiny plots", a new three-dimensional narrative mode is created, and the new space for novel narration is opened up. The ever-changing narrative time in text is conducive to attractive stories. For a number of renowned writers, the narrative time lines bring their works eternal charm. Natsume Soseki is also an outstanding author who is master in manipulating narrative time. Taking his novel The Gate as example, this paper analyzes the narrative time of Natsume Soseki's literary work.

\section{Narrative Time in The Gate}

Nonlinear narrative time mode. French narratologist Tzvetan Todorov said, "in a sense, discourse time is linear time, but the story time is three-dimensional. In the story, several events can occur at the same time, but they must be described one by one. Then, a complex image is projected into a straight line." [4] The "story" refers to "actual events; narration is telling stories. The story is three-dimensional, but story telling can only be linear" [5]. Gerald Genette called the incongruent phenomena between story time and narrative time as "anachronies", which mainly include flashbacks and flashforwards. In Natsume Soseki's novel The Gate, the narrative time is "nonlinear", while flashbacks are the main factor that leads the story to anachrony narrative mode.

The normal time sequence of the story in The Gate went as the following. Sosuke and Yasui made friends; Oyone and Sosuke fell in love with each other; they got married and then abandoned by the society; all their three kids died young; their peaceful marriage life is threatened by growing crises. But the time line in the works is distorted. The first chapter of the novel describes an autumn afternoon, which shows that the starting point of the novel is Oyone and Sosuke's peaceful but insecure marriage life. Then the story unfolds, and the author used the approach of "external analepsis" to describe the following events. Their three kids died young; they were abandoned by the society, and lived with shackles of "crime" and "punishment"; Sosuke and Yasui made friends; Oyone and Sosuke fell in love and got married. The so-called "external analepsis" refers to a flashback to a time before the narrative started. This arrangement of narrative time helps the author to create characters. Sosuke was a vigorous young man came from a wealthy family, but then he became an unfortunate people whose live was difficult. Marriage with Oyone was the watershed of his life. As a progressive intellectual, Sosuke survived in the crack of "love" and "sin". The arrangement of narrative time helps readers to feel Sosuke's lonely and helpless, and arouses their curiosity and sympathy. After reading, readers have further consideration on reasons for this tragedy, and deep thinking on the moral and ethical standards during Meiji Era.

At the beginning of the novel, Sosuke was faced with layoffs and salary cuts, but he had to look after his younger brother. Through the flashback afterwards, readers learn that Sosuke came from a wealthy family. When he was young, Sosuke enjoyed rich and careless life. But his uncle occupied their family property after his father's death. Then the landlord got familiar with Sosuke. The landlord wanted to introduce Yasui to Sosuke, with uncovered the past story of Sosuke, Yasui and Oyone. The starting point this flashback was earlier than the starting point of narrative time, while the ending point fell within the narrative time. The "mixed flashback" paves the ground for story narration, makes the whole story more compact, flexible and attractive. 
Durations combined fast and slow speeds. Duration is the relation between story time and discourse time, namely the speed of events. [6] It can be divided into five categories: pause, ellipsis, summary, scene and deceleration. In Natsume Soseki's novel The Gate, the author uses different types of duration to describe different events, and control the speed of story development. The pace combined fast and slow speeds builds unique aesthetic artistic conception.

Pauses are used frequently in The Gate, and they often contain deeper meanings; taking the opening of the novel as an example,

SŌSUKE had been relaxing for some time on the veranda, legs comfortably crossed on a cushion he had set down in a warm, sunny spot. After a while, however, he let drop the magazine he had been holding and lay down on his side. It was a truly fine autumn day, the sun bright, the air crisp, and the clatter of wooden clogs passing through the quiet neighborhood echoed in his ears with a heightened clarity. Tucking one arm under his head, he cast his gaze past the eaves at the expanse of clear blue sky above. Compared to the tiny space he occupied here on the veranda, this patch of sky appeared extremely vast. Thinking what a difference it made, simply to take in the sky in the rare, leisurely fashion afforded by a Sunday, he squinted directly at the blazing sun for a few moments,...

The story begins in a leisurely afternoon. The author used pause here to slow down the pace of story development. The soothing tone leads readers to enter the story quietly. By using words like "tiny" "squint" "blazing" and "dazzling", the author presupposed the emotional keynote and ethical judgment position. Readers do not know what will happen, but they can feel dangers hidden beneath the quiet. In this "fine autumn day, the sun bright, the air crisp, and the clatter of wooden clogs passing through the quiet neighborhood", Sosuke "let drop the magazine he had been holding and lay down on his side". It can be found that Sosuke have little leisure time. The desolation between them and outside streets and pedestrians helps to emphasize the isolation status of the couple. This pause stretches readers' psychological time, and guides them to feel characters' inner feeling.

Ellipsis and summary are also commonly used methods in the novel. The most classic one is the description of Sosuke and Oyone's love story.

The drama commenced at winter's end, when the faint signs of spring were just emerging, and reached its climax when the cherry blossoms scattered, giving way to fresh green leaves. It had been a life-and-death struggle. Their agony could be likened to that of raw, green bamboo being roasted over a hot flame until the oil came out. The unwary couple had been suddenly knocked over by a furious wind. By the time they got back on their feet, their entire world was covered with grit. They found themselves likewise encrusted, yet they had no inkling of when the storm wind had blown them over.

As the narrator of the story, Natsume Soseki described Sosuke's sunny life and his friendship with Yasui in his youth hood in the fourteenth chapter. Oyone was Yasui's fiancee, and she met Sosuke through Yasui. In this flashback, Natsume Soseki described how Sosuke and Oyone knew each other in detail. Then, he used the film creation method of montage to describe how they violated the moral rule for their "natural love". The description is extremely beautiful, which creates a fuzzy and clear picture for readers. "The unwary couple had been suddenly knocked over by a furious wind. By the time they got back on their feet, their entire world was covered with grit." Ellipsis is used here. In this simple sentence, time has been concentrated, while space has been changed. Hardship and loneliness of Sosuke and Oyone has been detailed described, and the narration here is an obvious flashback. The narrator used ellipsis to draw back the narration time. This ellipsis also gives readers room to imagination, and feel characters' fierce ideological struggle.

Frequencies. The so-called frequency refers to the relation between the number of times an event occurs in the story and the number of times it is mentioned in the narrative. There are three main frequential modes. Singulative telling means recounting once what happened once. Repetitive telling refers to recounting several times what happened once. Iterative telling means recounting once what happened several times. [7]

In the novel The Gate, Natsume Soseki used repetitive telling to make the beginning echoes with the end. As mentioned above, the novel begins in an autumn afternoon, when Sosuke and his wife were sitting in the sun and chattering in veranda. At the end of the story, they were still sitting in the sun in veranda. It was a winter afternoon; daily conversation between husband and wife carried out. 
"True, but then it will be winter again before you know it," Sosuke said, "head lowered, as he snipped away with the scissors." The circular narrative mode is formed here. The whole story starts in autumn and ends in winter, showing the emotional tone and ethical position of the novel, helping readers to feel Sosuke and Oyone's peaceful marriage life which was threatened by growing crises. It seems that Sosuke has passed a life crisis, but he still worries about the coming winter. Readers can learn Sosuke's ethical burden, and sympathize his despair. Seemingly happy, their life actually ends in tragedy.

In addition, the author repeatedly told readers that the couple did not have children. Even the toys in shops reminded Sosuke of the fact. For the couple, children were crystallization of love, and their hope for life; children represented that their sins had been forgiven. They had three babies, but no child survived. The fact suffered them greatly. The repetitive telling used here emphasizes their irreparable regret, and the guilty feeling for what they had done. The book is filled with unspeakable sadness which leads the readers to sympathize and ponder the couples' experience.

\section{Narrative Effects of Emphasizing Social Ethics}

The Gate was originally serialized in Asahi Shimbun between March to June, 1910. It attracted extensive attention of the society. At that time in Meiji Era, the mass media was not developed in Japan. The writer created literary works through the medium of newspaper. In 1907, Natsume Soseki quit his job at a university and became a full-time writer in Asahi Shimbun, which was considered as an amazing feat and caused public outcry. Later, Natsume Soseki serialized a number of novels in the newspaper, including The Poppy, The Miner, Sanshirō, And Then and The Gate. He received more and more highly appraises, and became a distinguished writer.

The story of The Gate happened after Meiji Restoration, when Japan quickly went on the path of capitalist development and modernization. As a literature master with strong sense of social responsibility, Natsume Soseki was keenly aware of the dramatic changes in the public ideology. His had extremely keen views on social issues, and paid attention to the disadvantages of Western civilization. In 1911, Natsume Soseki made a speech named Civilization and Enlightenment of Modern Japan in Wakayama-Ken. He pointed out that, the civilization process of Western was spontaneous, while Japanese civilization was passive and superficial. Japanese were catching up with the West, but they did not absorb the essence of Western civilization. Thus, the development of society was unbalanced, while people were restless, superficial, tired and despair. With such a deep insight into the current situation of Japanese society, Natsume Soseki used nonlinear narrative time, durations combined fast and slow speeds, and frequencies alternated with simple and repeated paces in the novel The Gate. He also paid attention to psychology time in his novel. This mode helps the author to express internalized meanings. At that time, Japan suffered the conflicts between ideal and reality, modern and tradition, Eastern culture and Western culture. Through the medium of Asahi Shimbun, The Gate aroused reader's awareness on the great moral crisis in Japan. People further introspected their "egoism" and "self center" conceptions. Thus, the book is of profound guiding significance on social ethics.

\section{Acknowledgement}

Fund Project: This project is one of the outcomes of the research, Study on Natsume Soseki's Novels from Ethical Literary Criticism Perspective, which is supported by Foundation for Philosophy and Social Science Research Projects in Higher Education Institutions of Jiangsu Province in 2016 (Project number: 2016SJD750052); Research on Narrative Time in Natsume Soseki's Novels, which is supported by Research Foundation for Young Scholars in Tianping College of Suzhou University of Science and Technology (Project number: TPQN2016004); Research on Twentieth Century Japanese Critical Theories, which is supported by Foundation for MOE (Ministry of Education in China) Projects of Humanities and Social Sciences (Project No. 15YJA752001). It also belongs to 2016 Research Programs sponsored by Qing Lan Project in Higher Education Institutions of Jiangsu 
Province, and one of the outcomes of the research, Ethical Orientation for Youth in Natsume Soseki's Novels, which is supported by Foundation for Scientific Research Projects for University Students.

\section{References}

[1] X.M. Wang, Checking, Integration and Resistance: A Study of Translations by the Xueheng School, University of International Business and Economics Press, Beijing, 2014, p98

[2] T. Todorov, The analysis of literary works, in: X.P. Wang (Eds.) A Glossary of Critical Terms in Literary Theory, p359

[3] Y.E. Wang, Research on opera of gifted scholars and beautiful ladies during Ming and Qing Dynasties, Shanghai Classics Publishing House, Shanghai, 2014, p278

[4] T. Todorov, Narrative discourse, in: Y.D. Zhang (Eds.), Narratology, p294

[5] C.L. Wang, Study of narrative discourse in French Narratology, J. Academic Exchanges. 1 (2010).

[6] G. Genette, Narrative Discourse: An Essay in Method. W.R. Wang (Trans), China Social Sciences Press, Beijing, 1990, p54

[7] S. R. Kenan, Narrative Fiction: Contemporary Poetics, J.Q. Yao, et al. (Trans), SDX Joint Publishing Company, Beijing, 1989, pp102-104. 